\title{
Peculiarities of ultrasound diagnostics of paraurethral glands in women of fertile age
}

\author{
V. M. Grygorenko ${ }^{\circledR A, F, E}$, O. V. Romashchenko ${ }^{A, C, F, D}$, V. V. Biloholovska ${ }^{A, B, C, D}$, \\ M. O. Kosiukhno $\mathbb{D}^{B}$, S. M. Melnykov $\mathbb{B}^{B}$, A. L. Klius $\mathbb{D}^{\mathrm{E}}$ \\ State Institution "Institute of Urology of the National Academy of Medical Sciences of Ukraine”, Kyiv
}

A - research concept and design; B - collection and/or assembly of data; C - data analysis and interpretation; D - writing the article; $\mathrm{E}$ - critical revision of the article; $\mathrm{F}$ - final approval of the article

Aim. Evaluation of ultrasound diagnostics of paraurethral glands considering their types of location in women of fertile age.

Materials and methods. A gynaecological, sexological and ultrasound study of 94 women in the age from 24 to 42 (average age $31.01 \pm 6.60$ ) was carried out.

Determination of paraurethral glands during ultrasound study was conducted in the format of grey scale (B-mode) using the Doppler colour flow mapping and evaluation of Doppler indices of paraurethral glands both before and after sexual stimulation. To optimize the paraurethral glands visual view at the beginning of examination urinary bladder was catheterized and a balloon, filled with gel, was inserted into vagina.

Results. The front type of paraurethral glands location was found in the accumulation of glandular tissues in regard to the distal part of urethra in $67(71.2 \%)$ of the examined, back type - in the area of back urethra in $19(20.2 \%)$, diffuse type - along urethra in $7(7.5 \%)$ and absence - in $1(1.1 \%)$. Paraurethral glands were visualized in the form of clear isoechogenic oval formation with the following dimensions: length $-2.20 \pm 0.60 \mathrm{~cm}$, width $-1.52 \pm 0.40 \mathrm{~cm}$, thickness $-1.30 \pm 0.30 \mathrm{~cm}$, and volume $-4.75 \pm 0.50 \mathrm{~cm}^{3}$.

The diameter of vessels in the paraurethral glands area was between $0.17 \mathrm{~cm}$ and $0.21 \mathrm{~cm}$ in calm state and $0.39-0.41 \mathrm{~cm}-$ during stimulation. Maximum systolic speed of blood flow (Vps) in calm was $8.9-11.1 \mathrm{~cm} / \mathrm{sec}$, while in sexual stimulation it was $13.9-14.1 \mathrm{~cm} / \mathrm{sec}$, resistance index (IR) $-0.60-0.62$ and $0.63-0.68$, respectively, pulsation index (IP) $-1.22-1.44$ and $1.61-1.72$, respectively.

Conclusions. The ultrasound study of vessels of paraurethral glands, when Doppler method is used according to the suggested methodology, gives the opportunity not only to identify its anatomical structure, but also to determine its types. In CDC the increase of diameter of vessels and the optimization of vessels image in the area of paraurethral glands in case of sexual stimulation were marked.

\section{Особливості ультрасонографічної діагностики парауретральних залоз у жінок фертильного віку}

В. М. Григоренко, О. В. Ромащенко, В. В. Білоголовська, М. О. Косюхно,

\section{С. М. Мельников, А. А. Клюс}

Мета роботи - оцінювання ультрасонографрічної діагностики парауретральних залоз, враховуючи типи їхньої локалізації в жінок репродуктивного віку.

Матеріали та методи. Здійснили гінекологічне, сексологічне, ультрасонографрічне обстеження 94 жінок-волонтерок віком 24-42 роки (середній вік - 31,01 $\pm 6,60$ ). Парауретральні залози під час УЗД визначали у форматі сірої шкали (В-режимі), використовуючи кольорове доплерівське картування, оцінювали доплерометричні індекси судин парауретральних залоз до та після сексуальної стимуляції (перегляд пацієнткою еротичного фільму впродовж 20 хвилин та нанесення на передню стінку піхви збуджувального лубриканта). На початку дослідження для покращення візуалізації парауретральних залоз виконали катетеризацію сечового міхура, в піхву ввели балон, заповнений гелем.

Результати. Передній (меатальний) тип локалізації парауретральних залоз (накопичення залозистої тканини у проєкції дистального відділу уретри) виявили в 67 (71,2%) обстежених, задній тип (у зоні задньої уретри) - в 19 (20,2%), дифузний тип (вздовж уретри) - в 7 (7,5%), рудиментарний -в 1 (1,1 \%) випадку. Парауретральні залози візуалізувалися як чітке ізоехогенне овальне утворення, що має такі розміри: довжина $-2,20 \pm 0,60 \mathrm{~cm}$, ширина $-1,52 \pm 0,40 \mathrm{~cm}$, товщина $-1,30 \pm 0,30 \mathrm{~cm}$, об'єм $-4,75 \pm 0,50 \mathrm{~cm}^{3}$.

Діаметр судин у зоні парауретральних залоз у спокої - 0,17-0,21 см, при стимуляції - 0,39-0,41 см. Максимальна систолічна швидкість кровотоку (Vps) у спокої становила 8,90-11,10см/с, при сексуальній стимуляції -13,9-14,1cм/c, індекс резистентності (IR) - 0,60-0,62 та 0,63-0,68, індекс пульсативності (IP) - 1,22-1,44 та 1,61-1,72 відповідно. Зону $\mathrm{G}$ виявили в $90,4 \%$ обстежених.

Висновки. Ультрасонографічне дослідження з використанням методу доплерографії судин парауретральних залоз за запропонованою методикою дає змогу не тільки ідентифікувати це анатомічне утворення, але і встановити типи його локалізації, особливості кровотоку судин парауретральної зони, точки G у стані спокою та на тлі сексуальної стимуляції.
Key words: paraurethral glands, ultrasound, Doppler colour flow mapping.

Pathologia 2021; 18 (2), 203-210

*E-mail: grygorenkosı@ gmail.com

Киючові слова: парауретральні залози, ультразвукова Аіагностика, кольорове Аоплерівське картування.

Патологія. 2021. T. 18, № 2(52). C. $203-210$ 
Ключевые слова: парауретральные железы, ультразвуковая Аиагностика, цветное Аопплеровское картирование.

Патология. 2021.

T. 18, № 2(52).

C. 203-210

\section{Особенности ультрасонографической диагностики парауретральных желёз у женщин фертильного возраста}

\section{В. Н. Григоренко, О. В. Ромащенко, В. В. Белоголовская, М. А. Косюхно, С. Н. Мельников, А. А. Клюс}

Цель работы - оценка ультрасонографической диагностики парауретральных желёз с учётом типов их локализации у женщин репродуктивного возраста.

Материалы и методы. Проведено комплексное гинекологическое, сексологическое и ультрасонографическое обследование 94 женщин-волонтеров в возрасте 24-42 года (средний возраст -31,01 \pm 6,60). Парауретральные железы в ходе УЗИ определяли в режиме серой шкалы (В-режиме) с использованием цветного допплеровского картирования, оценивали допплерометрические индексы сосудов парауретральных желёз до и после сексуальной стимуляции (просмотр пациенткой эротического фильма в течение 20 минут и нанесение на переднюю стенку влагалища возбуждающего лубриканта). В начале исследования для улучшения визуализации парауретральных желёз проводили катетеризацию мочевого пузыря и вводили во влагалище баллон, заполненный гелем.

Результаты. Передний (меатальный) тип локализации парауретральных желёз (при накоплении железистой ткани в проекции дистального отдела уретры) установлен у 67 (71,2%) обследованных, задний тип (в зоне задней уретры) -у 19 (20,2%), диффузный тип (вдоль уретры) - у 7 (7,5 \%), рудиментарный - у 1 (1,1 \%). Парауретральные железы визуализировались в виде чёткого изоэхогенного овального образования такими размерами: длина $-2,20 \pm 0,60$ см, ширина $-1,52 \pm 0,40$ см, толщина $-1,30 \pm 0,30$ см, объём $-4,75 \pm 0,50$ см $^{3}$. Диаметр сосудов в парауретральной зоне в покое - 0,17-0,21 см, при стимуляции - 0,39-0,41 см. Максимальная систолическая скорость кровотока (Vps) в покое составляла 8,9-11,1 см/c, при сексуальной стимуляции - 13,9-14,1 см/с, индекс резистентности (IR) 0,60-0,62 и 0,63-0,68, индекс пульсативности (IP) - 1,22-1,44 и 1,61-1,72 соответственно. Зона G обнаружена у $90,4 \%$ обследованных.

Выводы. Ультрасонографическое исследование методом допплерографии сосудов парауретральных желёз по предложенной методике позволяет не только идентифицировать это анатомическое образование, но и установить типы его локализации, в особенности кровотока сосудов парауретральной зоны, точки G в состоянии покоя и на фоне сексуальной стимуляции.

Study of anatomic structure and functional activity of paraurethral glands in today's conditions attracts attention of world scientific community [1-5]. In spite of the fact, that attempts to determine the anatomic structure and functional activity of paraurethral gland have been known since 1672 [6-13], a list of contradictory and unclarified aspects regarding morphological and functional characteristics of this anatomic structure is preserved $[1,5]$.

There are certain contradictions in the determination of homology of paraurethral glands with the anatomic body in a male organism and evaluation of its functional activity $[11,14-18]$.

Paraurethral glands' comparison of characteristics with the homologous men's organ shows that male prostate gland surrounds urethra, meanwhile the accumulation of women's paraurethral glands are located alongside urethra [11]. The thickness of walls and the length of female urethra limit the location of paraurethral glands, and that is why their size is smaller compared to the male prostate gland and constitutes in average $3.3 \times 1.9 \times 1.0 \mathrm{~cm}$, while the average weight is 4 times smaller (3.9 and 23.7, respectively) $[11,19]$.

Morphological research of the structure of paraurethral glands in women proves that in the stroma of this anatomic formation ducts similar to male prostate gland and smooth muscles are found, although their muscle component is more developed. A histological study of tissues of paraurethral glands by Rudolf Virchow gave grounds to reveal amyloid bodies, typical only for male organ [10].

In 1947, J. Huffman created three-dimensional models of paraurethral glands. To perform that model, he filled anatomic structures of urethra with hot wax and received characteristic features of paraurethral glands' structure, size and number. The author noticed that this anatomic formation is similar to how a tree looks like. In his view, the urethra resembles a tree trunk, while tubes of paraurethral glands coming therefrom are similar to tree branches [20]. Taking anatomical data of Huffman's revolutionary wax model, M. Zaviacic (1999) found different types of paraurethral glands according to his pathoanatomic cross-sectional studies: anterior (meatal) type, posterior type, diffuse type, rudimentary type, rare middle tipe, dumbbell configuration [7,11]. According to the opinion of Huffman (1948), M. Zaviacic et al. (1985), Wernert et al. (1991), in 70 per cent of women the accumulation of glandular tissue is observed along the frontal distal part of urethra [20-22].

The system of outgoing ducts of paraurethral glands is presented by numerous channels, through which ejaculate, extracted during orgasm, comes to urethra. It should be mentioned that in some cases extractions from the female urethra are so abundant that they serve as a reason for comparison with the phenomenon of male ejaculation [9,23-25]. A high amount of alkaline phosphatase was established, with variable PSA levels both in the vagina and in the female ejaculate [23-27].

Paraurethral glands as an active functioning organ in a female body have become the center of attention of clinicians and pathologists only in the second half of XX century. The data regarding the unified embryological origin of paraurethral glands and male prostate from the urogenital sinus have accumulated [28-30].

For a long time, the majority of skeptical scholars had not recognized embryological findings, as a confirmation of the existence of homology of two genitourinary structures and completely disagreed with the understanding of paraurethral glands as an actively functioning organ in a female body. The vestigial concept based on the macroscopic difference in the size of both sexes at that moment was the main one, while the difference in size of glands 
has been many times used to substantiate their functional inadequacy.

In the opinion of Wernert and coauthors the accumulation of paraurethral glandular tissue along urethra and also in the place between the wall of urethra and the frontal wall of vagina should be recognized as a rudimentary non-functional anatomic formation in a female body (vestigial concept) [22].

In these conditions M. Zaviacic and coauthors contrary to the traditional views and using the fundamental research persuasively proved the functional activity of paraurethral glands in a female body during all stages of life (non-vestigial concept) $[18,22]$. Vestigial theory was refuted by M. Zaviacic et al (2000) on the basis that morphologically mature secretarial and basal cells were established in the tissues of paraurethral glands of women of reproductive and perimenopausal age during electronic microscope study. It was proved that paraurethral glands do not disappear in the process of embryological development (as it was regarded before), while in 90 per cent of cases they actively develop in a mature glandular tissue with full-fledged secretarial function (non-vestigial concept) [3].

In 2001 on the basis of studies of M. Zaviacic and coauthors the Federative International Committee on Anatomical Terminology (FICAT) during its meeting, which took place in Orlando (Florida, USA) included the concept of female prostate into the list of Histological Terminology, having prohibited the use of terms "Skene's paraurethral glands" or "paraurethral ducts" to mark female prostate.

In today's conditions the active study of anatomic and functional peculiarities of development of paraurethral glands continues [1]. In these circumstances the study of this anatomic formation in a female organism is related to great research difficulties, because paraurethral glands can constitute the object of research only in case of autopsy in women, which is by itself related to a list of legal prohibitions [16].

The optimization of diagnostics of paraurethral glands and the determination of their role in the formation of urogenital and sexual disorders in a female body remains an obvious problem of clinical medicine.

The presented work is based on the idea of revaluation of traditional approaches to the standards of identification of paraurethral glands in women of fertile age considering the types of their location.

As of today, in the world's clinical practice, these diagnostical criteria are not standardized and received little research.

\section{Aim}

Evaluation of diagnostics of ultrasound evaluation of paraurethral glands considering their types of location in women of fertile age.

\section{Materials and methods}

A gynecological, sexological and ultrasound study of 94 women in the age from 24 to 42 (average age $31.01 \pm 6.60$ ), was carried out.

An examination of women-volunteers, who consented to it, was carried out according to the rules of ethical committee and confidentiality requirements.
An examination of women-volunteers, who consented to it, was carried out according to the rules of ethical committee and confidentiality requirements.

It was suggested to use new methods of check-up to optimize ultrasound diagnostics of paraurethral glands. Before the examination bladder was catheterized and a $50.0 \mathrm{ml}$ vessel, filled with gel, was introduced into the vagina. Implementation of these methods of ultrasound study, in our opinion, leads to alleviate visualization of paraurethral glands. In accordance with this research method, paraurethral glands were considered as a separate anatomic formation.

As previously established, the ultrasound study with Doppler method to investigate vessels of this anatomic formation permits the evaluation of indicators that describe blood flow with high accuracy. Under this scenario patients do not experience complications and consequences that are undesirable.

The ultrasound diagnostic expert class system XARIO of TOSHIBA in the format of grey scale (B-mode) was used in the study. Also, Doppler colour flow mapping (CFM) was employed during the examination of paraurethral zone and Doppler indices were determined.

The use of Advanced Dynamic Flow allows CFM receiving high dimensional image to see any vascularization, including insignificant one, and to establish even vague flows.

The program Panoramic View was thought to optimize view of large-format picture having two-dimension effect and optimization in research of topographic anatomy of paraurethral glands area.

There were two kinds of transmitters in the research: linear multi-frequency transmitters $(5.0-12.0 \mathrm{MHz})$ and endocavitary ones $(9.0-14.0 \mathrm{MHz})$.

In the format of CFM vascular angioarchitecture and characteristics of parenchymatous blood flow in paraurethral glands were assessed. The specific studied area included paraurethral glands and G-spot (their availability, characteristics of localization, intensity and symmetry).

In order to evaluate Doppler signals the selected scanning angle between ray and vessel (ranged between 0 and 40 degrees) was used.

We evaluated parameters of 3-4 complexes. Linear size was measured - diameters of vessels of the described formations and evaluation of Doppler parameters: peak systolic speed of blood flow (Vs cm/s), resistive index (IR), and pulsatility index (IP).

During the examination no one used contraceptives or hormone medicaments. The examination of women took place during the first phase of menstrual cycle (between the $5^{\text {th }}$ and $10^{\text {th }}$ days of cycle).

In course of visualization of the paraurethral glands, the patient was placed on the back. We introduced anesthetic (Cathejell) into urethra. Bladder was catheterized via Foley catheter No. 12 or No. 14, using the vessel, filled with gel, for $10-15 \mathrm{~cm}^{3}$. At the finish of the study, we removed the catheter and prescribed the 3-5 days antibacterial therapy. Our aim was to avoid potential complications after the examination [31].

The inspection was carried out in the state of calm as well as after 20-30 minutes of sexual stimulation using erotic video. The study was performed if convenience for the patient was ensured. 
The ultrasound parameters data of women's paraurethral glands $\mathrm{M} \pm \mathrm{SD}$, were analyzed using Wilcoxon signed-rank test and Spearman correlation r-test. Stastically significant difference was considered for $P<0.05$. Analysis was performed using SPSS 22.0 (IBM, Armonk, NY, 53595fc69139e7c88dec).

\section{Results}

The analysis of data of paraurethral glands ultrasound study allowed to make the following findings. We found the front (meatal) type of paraurethral glands location in the paraurethral glands' accumulation of tissues in regard to the distal part of urethra in $67(71.2 \%)$ of examined (Fig. 1, 2), back type - in the area of back urethra in 19 (20.2\%) (Fig. 3,4,5), diffuse type - along urethra in 7 (7.5\%) (Fig. 6,7,8), and absence - in 1 (1.1 \%) (Fig. 9).

During ultrasound study of paraurethral glands using the mode of gray scale this anatomic formation was in the form of clear isoechogenic oval with the following dimensions: length $-2.20 \pm 0.60 \mathrm{~cm}$, width $-1.52 \pm 0.40 \mathrm{~cm}$, thickness $-1.30 \pm 0.30 \mathrm{~cm}$, and volume $-2.30 \pm 0.70 \mathrm{~cm}^{3}$.

Sexual stimulation during 20-30 minutes (viewing erotic video) was accompanied by the increase in the diameter of paraurethral glands vessels, intensification of blood flow and brightness of sonographic image during CFM in the regime of energetic Doppler carding, and was characterized by the increase in the indices of blood flow of the studied zone elements (paraurethral glands and G-spot).

The diameter of vessels in the paraurethral glands zone was between $0.17 \mathrm{~cm}$ and $0.21 \mathrm{~cm}$ in calm, and $0.39-0.41$ $\mathrm{cm}$ - during stimulation.

Maximum systolic speed of blood flow (Vps) during CFM in calm was $8.90-11.10 \mathrm{~cm} / \mathrm{sec}$, while in sexual stimulation it was $13.90-14.10 \mathrm{~cm} / \mathrm{sec}$, resistance index (IR) $-0.60-0.62$ and $0.63-0.68$, respectively, pulsatility index (IP) $-1.44-1.22$ and 1.61-1.72 respectively.

There were determined positive correlation and significant difference between changing of ultrasound parameters of women before and after sexual stimulation; increasing of diameter of vessels in the paraurethral zone $(P<0.001$, $r=0.55)$, maximum systolic speed of blood flow $(P<0.001$, $r=0.4)$ and pusatility index $(P<0.05, r=0.2)$, while we didn't notice any correlation and statistically significant changes in resistance index $(P>0.05, r=-0.07)$.

In the conducted research the G-spot was found in $85(90.4 \%)$ of the examined. G-spot was visualized in the form of spheric thickening at the front wall of vagina at the distance $3.00-6.70 \mathrm{~cm}$ from introitus vaginae (Fig. 10).

We have noticed, that there is no correlation between paraurethral gland's location type and investigated ultrasound parameters $(P>0.05)$.

It should be noted that in every specific case the location of G-spot had its features. During ultrasound study the parameters of G-spot in calm (length - between 1.24 and $1.31 \mathrm{~cm}$, width - between $0.68 \mathrm{~cm}$ and $0.76 \mathrm{~cm}$, thickness - between $0.28 \mathrm{~cm}$ and $0.34 \mathrm{~cm}$, volume - between $0.1 \mathrm{~cm}^{3}$ and $\left.0.2 \mathrm{~cm}^{3}\right)($ Fig. 11,12,13) and at the background of video-erotic stimulation (length - between $1.34 \mathrm{~cm}$ and $1.38 \mathrm{~cm}$, width - between $0.75 \mathrm{~cm}$ and $0.84 \mathrm{~cm}$, thickness - between $0.38 \mathrm{~cm}$ and $0.54 \mathrm{~cm}$, volume - between $0.20 \mathrm{~cm}^{3}$ and $0.30 \mathrm{~cm}^{3}$ ) (Fig. 14) were established.

\section{Discussion}

For a long time, medical academic community, adhering to the vestigial concept, had not recognized paraurethral glands in female body as a functionally active organ. The results of research by M. Zaviacic et al., complying to the principles of interdisciplinary approach, have persuasively demonstrated the fairness of recognition of non-vestigial concept on paraurethral glands with the confirmation of the peculiarities of anatomic structure and functional activity during the whole life of a woman $[3,11,14-16,18,19,21,23,26]$.

It should be once again stated that the assessment of anatomic structure of paraurethral glands is conditioned by the list of difficulties caused by legal aspects in making autopsies [16].

At the same time there are only occasional data about clinical and paraclinical evaluation of functional activity of paraurethral glands in women of different age groups.

Results of Magnetic Resonance Imaging of paraurethral zone and ultrasound studies of urethrovaginal space accumulate, but remain non-systematic [32].

For instance, during magnetic resonance imaging of paraurethral glands in women F. Wimpissinger established the size of paraurethral glands without focusing on the types of their location [33].

The object of scientific discussion are not only anatomic and functional characteristics of paraurethral glands, but also the Grafenberg spot. In 1950 Ernst Grafenberg described an erogenous zone on the frontal wall of vagina, which for the first time was called G-spot by F. Addiego (1981) [34,35].

The expected Grafenberg spot is, approximately located in the projection of the pelvic part of urethra, contains periglandular and paraurethral tissues [36-39].

In the opinion of Crooks and Baur, "the G-spot contains a system of glands (Skene's glands) and ducts that surround the urethra" [40].

In 2008, G. L. Gravina et al. indicated that during ultrasound study of paraurethral zone the Grafenberg spot was established, but the image of this structure was not presented, which became the basis for debate [41].

In these circumstances the optimization of diagnostics of paraurethral glands and paraurethral zone is a demand of today. The methods of ultrasound study for vessels of paraurethral glands, using Doppler method, allow revealing the peculiarities of a separate anatomic formation considering the type of its localization and its character of development due to the individual features of paraurethral glands' branching. G-spot (projection of glandular tissue in relation to vagina) located in case of proximal and distal location of paraurethral glands was established in $80.4 \%$ of the studied patients.

The methods of examination proposed above enhance visualization of paraurethral glands and all its parts. It gives us the opportunity to expand perception about the characteristics of this anatomic formation according to the paraurethral glands' description with different kinds of their placement, character of localization and view on G-spot.

\section{Conclusions}

1. The ultrasound research that includes the Doppler method of paraurethral zone vessels on earlier catheterized bladder allows determining paraurethral glands as a unique anatomic formation. 

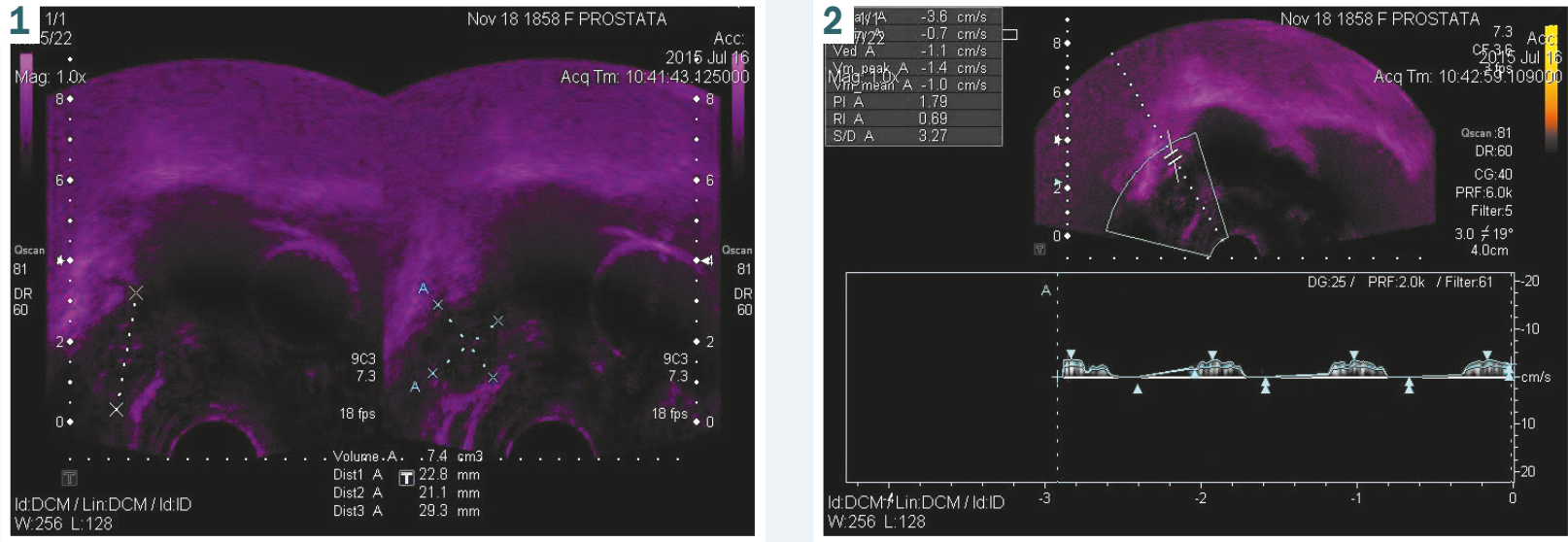

Fig. 1. Ultrasound study of paraurethral glands. Front type of paraurethral glands location in calm. Patient L., aged 34. In the projection of distal part of urethra an oval formation of isoechogenic structure with clear margins is visualized. Size: length $-2.28 \mathrm{~cm}$, width $-2.11 \mathrm{~cm}$, thickness $-2.39 \mathrm{~cm}$, and volume $-7.4 \mathrm{~cm}^{3}$.

Fig. 2. Ultrasound study of paraurethral glands (front type) in calm with the determination of Doppler indices. Patient L. Visualization of front type of paraurethral glands in the mode of gray scale. $V p s=3.60 \mathrm{~cm} / \mathrm{sec} ; \mathrm{IR}=0.69 ; \mathrm{IP}=1.79$.
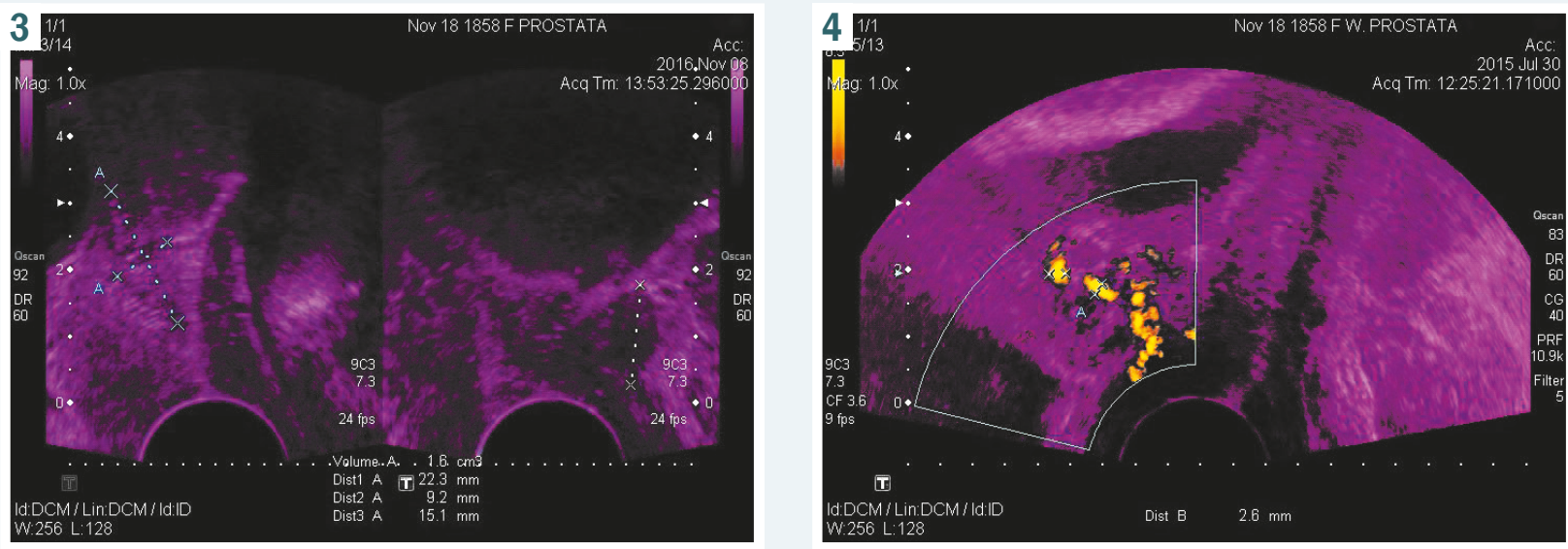

Fig. 3. Ultrasound study of paraurethral glands (back type) in calm. Patient P., aged 40 . In the projection of proximal part of urethra an oval formation of isoechogenic structure with clear margins and homogeneous structure is visualized. Size: length $-2.23 \mathrm{~cm}$, width $-0.92 \mathrm{~cm}$, thickness $-1.51 \mathrm{~cm}$, and volume $-1.60 \mathrm{~cm}^{3}$.

Fig.4. Ultrasound study of paraurethral glands (back type) with the determination of diameter of vessels at the background of video-erotic stimulation. Patient Ch., aged 34. In the projection of back urethra an oval flat formation of isoechogenic structure is visualized. During CFM a clear vascular image with the diameter of vessels up to $0.26 \mathrm{~cm}$ was established at the background of video-erotic stimulation.
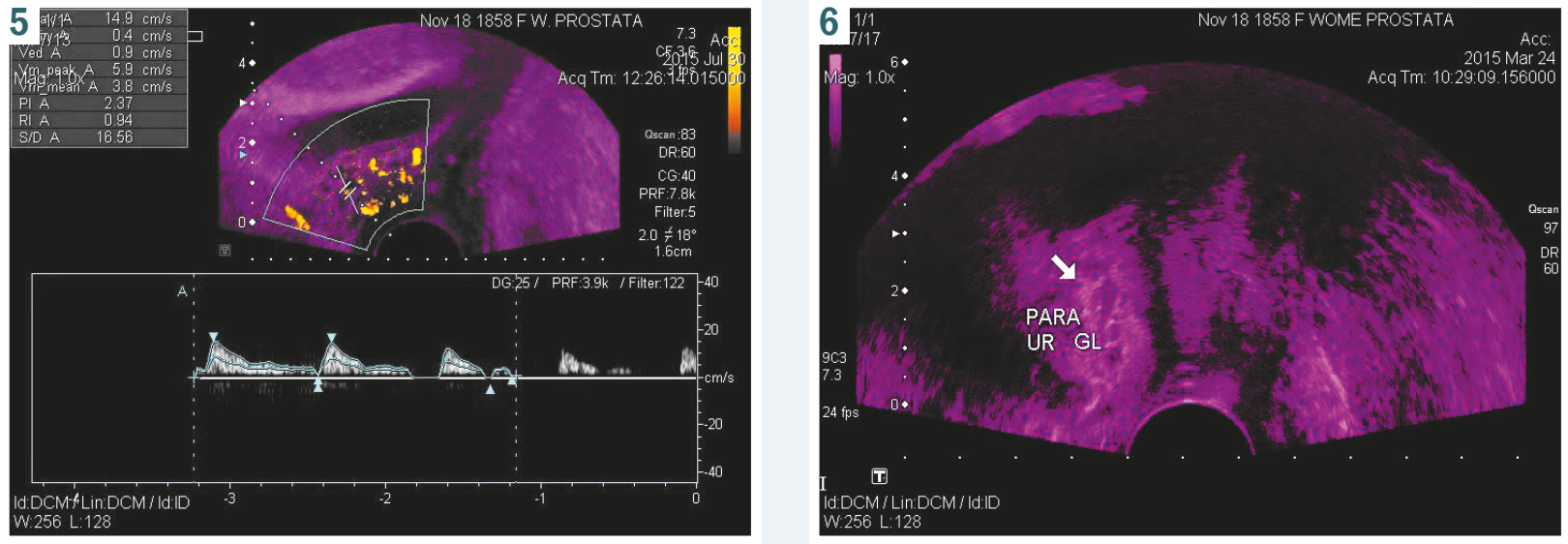

Fig. 5. Ultrasound study of paraurethral glands (back type) with the determination of Doppler indices of blood flow at the background of video-erotic stimulation. Patient Ch., aged 34. Back FPG type is verified. Increase in brightness of vascular image: $V p s=14.9 \mathrm{~cm} / \mathrm{sec} ; \mathrm{IR}=2.37$.

Fig. 6. Ultrasound study of paraurethral glands (diffuse type) in the regime of gray scale in calm. Patient P., aged 29. Diffuse type of paraurethral glands is verified. Steady accumulation of glandular tissue along urethra. 

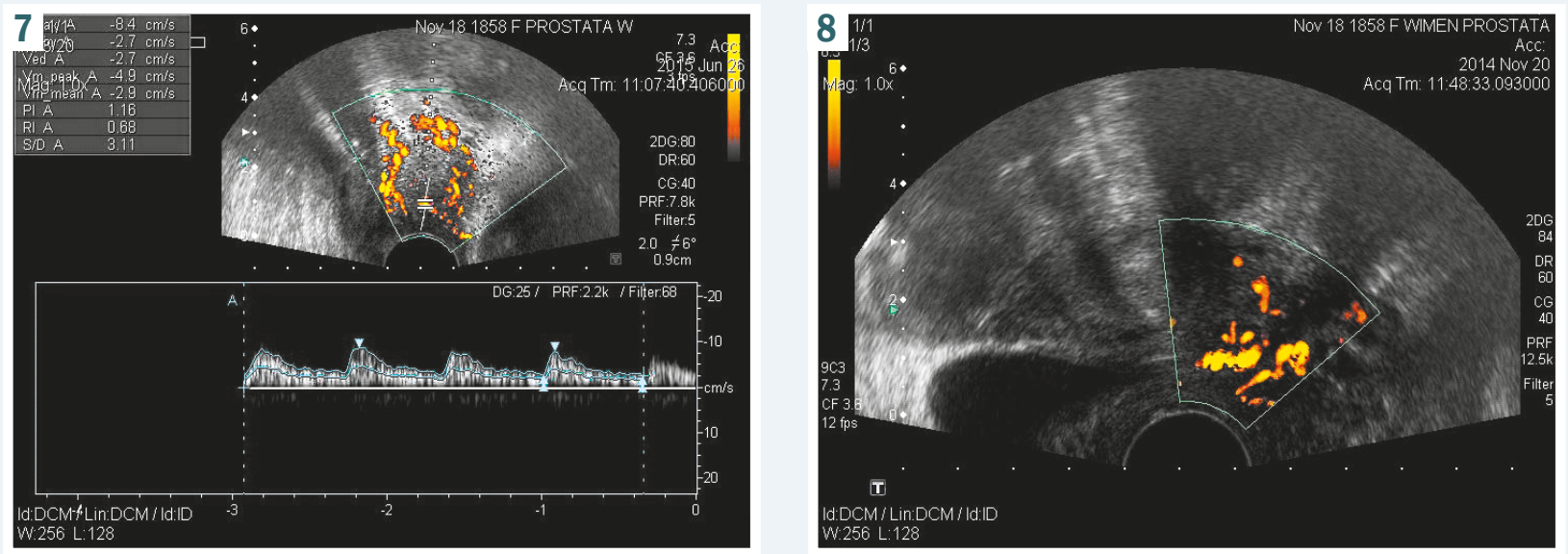

Fig. 7. Ultrasound study of paraurethral glands (diffuse type) at the background of video-erotic stimulation. Patient G., aged 30. Increase of blood flow in the stroma of paraurethral glands with the bright coloration of vascular image.

Fig. 8. Ultrasound study of paraurethral glands (diffuse type) with the determination of Doppler indices at the background of video-erotic stimulation. Patient G., aged 30. Steady accumulation of glandular tissue along urethra. Increase in blood flow in tissues of paraurethral glands with bright coloration of vascular image. Doppler indices of blood flow: $\mathrm{Vps}=8.40 \mathrm{~cm} / \mathrm{sec}, \mathrm{IR}=0.68 ; \mathrm{IP}=1.16$.
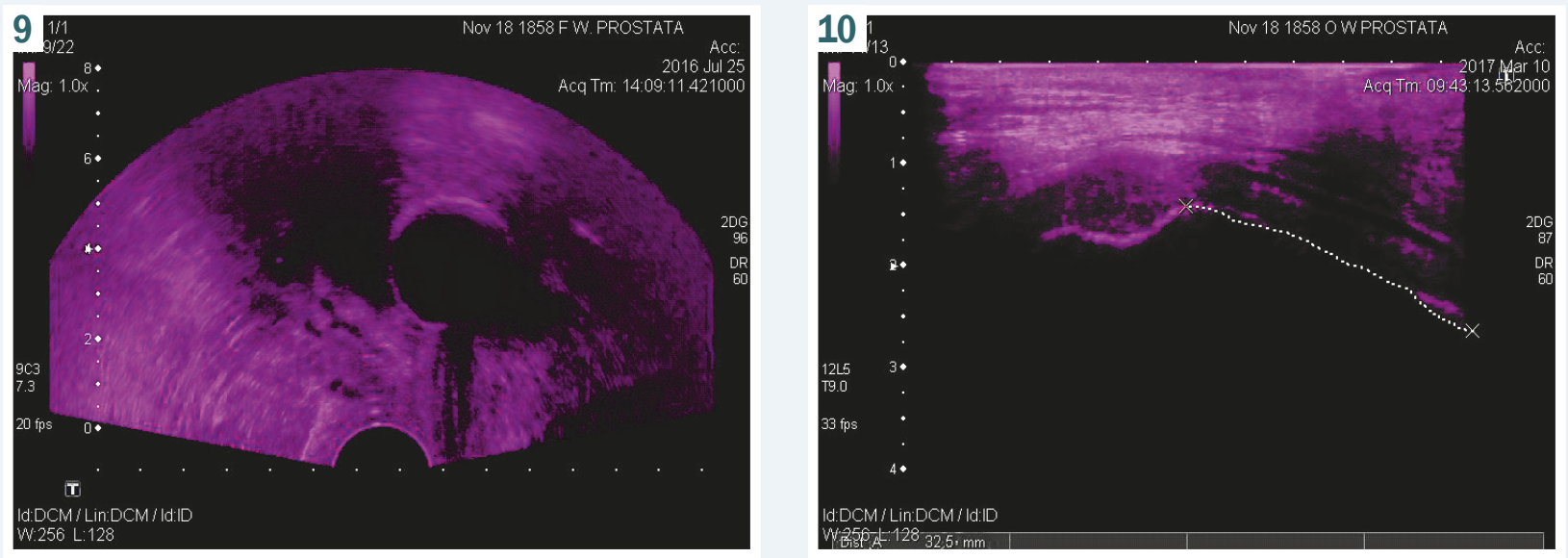

Fig. 9. Ultrasound study of paraurethral zone. Patient B., aged 33. Paraurethral glands were not verified.

Fig.10. Ultrasound study of G-spot in the mode of gray scale (B-regime). Patient W., aged 39. G-spot was found at the front wall of vagina as a thickened formation at the distance $3.25 \mathrm{~cm}$ from introitus vaginae.
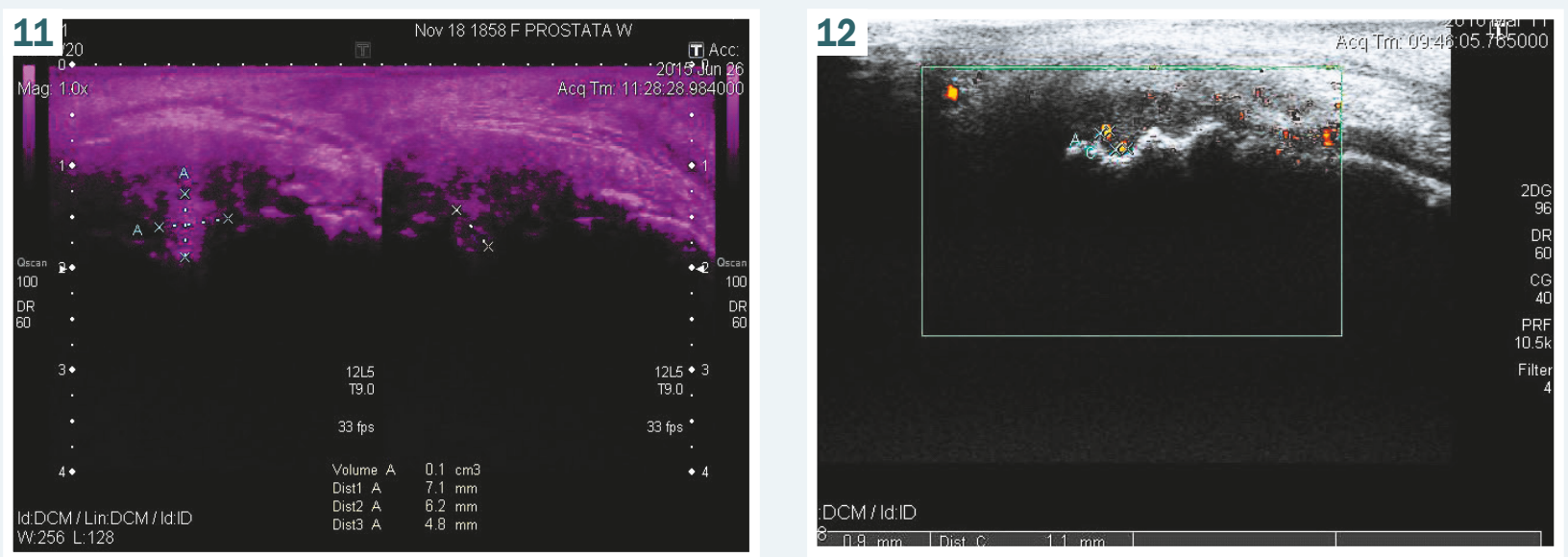

Fig. 11. Ultrasound study of G-spot in the mode of gray scale (B-regime) with the determination of its linear dimensions in calm. Patient G., aged 30. G-spot was found on the front wall of vagina in the form of thickened formation with the following size: length $-0.71 \mathrm{~cm}$, width $-0.62 \mathrm{~cm}$, thickness $-0.48 \mathrm{~cm}$, and volume $-0.11 \mathrm{~cm}^{3}$.

Fig. 12. Ultrasound study of G-spot in the regime of gray scale with the determination of diameter of vessels. Patient K., aged 37. In the stroma of G-spot the vessels with diameter between $0.1 \mathrm{~cm}$ and $0.11 \mathrm{~cm}$ are visualized. 

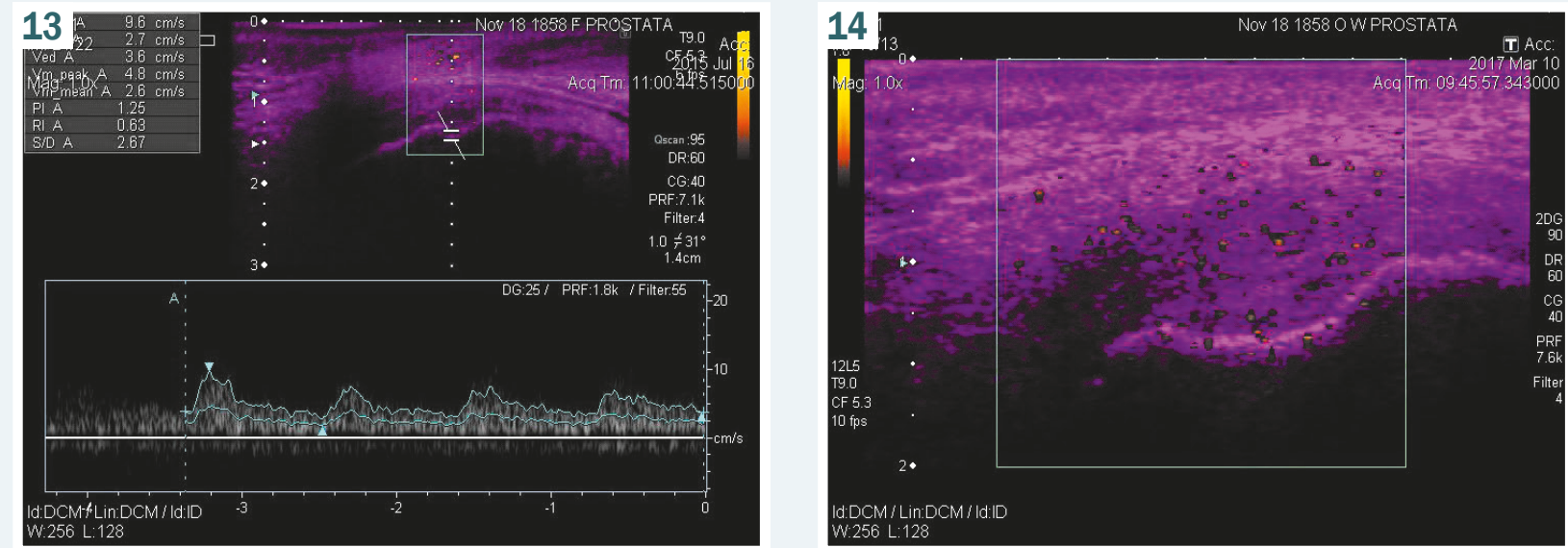

Fig. 13. Ultrasound study of G-spot in the mode of gray scale using Doppler method of this zone vessels in calm. Patient L., aged 34. Doppler indices of blood flow in vessels of G-spot: Vps $=9.6 \mathrm{~cm} / \mathrm{sec}, \mathrm{IR}=0.63, \mathrm{IP}=1.25$

Fig. 14. Ultrasound study of G-spot in the mode of gray scale using Doppler method of vessels of this zone during sexual excitement. Patient W., aged 39. In the stroma of G-spot numerous vessels are visualized. During CFM the intensification of vascular image in the form of vascular "flashes" was revealed.

2. Ultrasound investigation of paraurethral glands vessels using Doppler method in accordance with the suggested above methodology gives opportunity to identify paraurethral glands and to determine their types; as a result, we can study blood flow in paraurethral glands, G-spot both in calm and after video-erotic stimulation.

3. Consequently, the "front type" of paraurethral glands location was established in the accumulation of glandular tissue in regard to distal part of urethra in $67(71.2 \%)$ of the examined women. "back type" of paraurethral glands location was found in the zone of proximal part of urethra in $19(20.2 \%)$ of the examined women, "diffuse type" - placed along urethra in $7(7.5 \%)$ of the examined women, and absence in $1(1.1 \%)$ of the examined women.

4. Colored Doppler examination marked an increase in vascular diameter of vessels and optimization of vessels image in the area of paraurethral glands on the background of sexual stimulation during the 20-30 minutes erotic video, what is confirmed by statistical difference between investigated parameters.

5. The results of the obtained observations and their clinical illustrations allow us to draw a conclusion that using of investigated ultrasound methodology optimizes the visualization of woman's prostate gland zone and allows reaching high quality image and also allows to reach clarity of the described structures; this method of examination also allows evaluating the characteristic of blood flow.

Conflicts of interest: authors have no conflict of interest to declare. Конфлікт інтересів: віАсутній.

НаАійшла Ао редакції / Received: 15.10.2020

Після Аоопрацювання / Revised: 28.06.2021

Прийнято АО Аруку / Accepted: 05.07.2021

Information about authors:

Grygorenko V. M., MD, PhD, DSc, Senior Researcher, Head of

the Department of Restorative Urology and New Technologies,
State Institution "Institute of Urology of the National Academy of Medical Sciences of Ukraine", Kyiv.

ORCID ID: 0000-0003-3282-3709

Romashchenko 0. V., MD, PhD, DSc, Professor, Chief Researcher of the Department of Restorative Urology and New Technologies, State Institution "Institute of Urology of the National Academy of Medical Sciences of Ukraine", Kyiv.

ORCID ID: 0000-0002-0544-8758

Biloholovska V. V., MD, PhD, Head of the Ultrasound Department, State Institution "Institute of Urology of the National Academy of Medical Sciences of Ukraine", Kyiv. ORCID ID: 0000-0001-9003-704X

Kosiukhno M. O., Senior Laboratory Assistant of the Department of Restorative Urology and New Technologies, State Institution "Institute of Urology of the National Academy of Medical Sciences of Ukraine", Kyiv.

ORCID ID: 0000-0003-4818-9562

Melnykov S. M., MD, PhD, DSc, Chief Researcher of

the Department of Restorative Urology and New Technologies, State Institution "Institute of Urology of the National Academy of Medical Sciences of Ukraine", Kyiv.

ORCID ID: 0000-0001-8663-5995

Klius A. L., MD, PhD, Urologist of II Urology Department, State Institution "Institute of Urology of the National Academy of Medical Sciences of Ukraine", Kyiv.

\section{ORCID ID: 0000-0002-5001-2574}

\section{Відомості про авторів:}

Григоренко В. М., А-р меА. наук, старший науковий співробітник, зав. віААілу віАновної урології та новітніх технологій, $А$ " «нститут урології НАМН України", м. Київ.

Ромащенко О. В., А-р меА. наук, професор, головний науковий співробітник віААілу віАновної урології та новітніх технологій,

АУ "Інститут урології НАМН України", М. Київ.

Білоголовська В. В., канА. меА. наук, зав. віАділення ультразвукової діагностики, АУ "Інститут урології НАМН України", м. Київ. Косюхно М. О., старший лаборант віАділу віАновної урології та новітніх технологій, АУ “ннститут урології НАМН України", М. Київ. Мельников С. М., А-р меА. наук, головний науковий співробітник відАілу віАновної урології та новітніх технологій, АУ «ннститут урології НАМН України", м. Київ.

Клюс А. ^., канА. меА. наук, лікар-уролог ІІ урологічного віАділення, АУ "Інститут урології НАМН України", м. Київ.

\section{Сведения об авторах:}

Григоренко В. Н., А-р меА. наук, старший научный сотрудник, зав. отАелом восстановительной урологии и новейших технологий, ГУ "Институт урологии НАМН Украины", г. Киев. 
Ромащенко О. В., А-р меА. наук, профессор, главный научный сотруАник отАела восстановительной урологии и новейших технологий, ГУ “Институт урологии НАМН Украины”, г. Киев. Белоголовская В. В., канА. меА. наук, зав. отАелением ультразвуковой Аиагностики, ГУ «ИНститут урологии НАМН Украины", г. Киев.

Косюхно М. А., старший лаборант отАела восстановительной урологии и новейших технологий, ГУ “Институт урологии НАМН Украины", г. Киев.

Мельников С. Н., А-р меА. наук, главный научный сотрудник отАела восстановительной урологии и новейших технологий, ГУ „Институт урологии НАМН Украины», г. Киев. Клюс А. ^., канА. МеА. наук, врач-уролог II урологического отАеления, ГУ “Институт урологии НАМН Украины”, г. Киев.

\section{References}

[1] Biancardi, M. F., Dos Santos, F. C., de Carvalho, H. F., Sanches, B. D. \& Taboga, S. R. (2017). Female prostate: historical, developmental, and morphological perspectives. Cell Biology International, 41(11), 1174-1183. https://doi.org/10.1002/cbin. 10759

[2] Evatt E. J. (1911). A Contribution to the Development of the Prostate Gland in the Human Female, and a Study of the Homologies of the Urethra and Vagina of the Sexes. Journal of anatomy and physiology, 45(Pt 2), 122-130

[3] Zaviacic, M., Jakubovská, V., Belosovic, M., \& Breza, J. (2000). Ultrastructure of the normal adult human female prostate gland (Skene's gland). Anatomy and embryology, 201(1), 51-61. https://doi. org/10.1007/pl00022920

[4] Santos, F. C. A., \& Taboga, S. R. (2018). Female prostate: a review about the biological repercussions of this gland in humans and rodents. Animal Reproduction, 3(1), 3-18

[5] Chen, Y., Zhao, J. Z., Feng, R. E., Shi, J. H., Li, X. M., Fei, Y. Y., Shi, Y., Zhang, W., \& Zhang, F. C. (2016). Types of Organ Involvement in Patients with Immunoglobulin G4-related Disease. Chinese medical journal, 129(13), 1525-1532. https://doi.org/10.4103/0366-6999.184459

[6] De Graaf R. (1672). De mulierum organis generationi inservientibus. Tractatus novus demonstranstamhomines et animalia caetera omnia, quae viviparadicuntur, haud minus quam vivipara abovooriginem ducere. Leyden.

[7] Zaviacic, M., Zaviacicová, A., Brozman, M., Holomán, I. K., Bruchac, D., Oberucová, J., \& Kokavec, M. (1985). Prostata zeny alebo Skeneove zl'azy a vývody? (Dôvody pre návrat k pôvodnému termínu De Graafe) [The female prostate or Skene's glands and ducts? (Reasons for returning to De Graaf's original term)]. Ceskoslovenska gynekologie, $50(5), 372-377$.

[8] Korda, J. B., Goldstein, S. W., \& Sommer, F. (2010). The history of female ejaculation. The journal of sexual medicine, 7(5), 1965-1975. https://doi.org/10.1111//.1743-6109.2010.01720.x

[9] Skene, A. J. C. (1880). The anatomy and pathology of two important glands of the female urethra. NY: William Wood \& Co. http://resource. nlm.nih.gov/101316080

[10] Ribatti D. (2019). Rudolf Virchow, the founder of cellular pathology. Romanian journal of morphology and embryology = Revue roumaine de morphologie et embryologie, 60(4), 1381-1382.

[11] Zaviacic, M. (1999). The human female prostate : from vestigial Skene's paraurethral glands and ducts to woman's functional prostate. Slovak Academic Press. https://doi.org/10.1023/A:1019852411051

[12] Gittes, R. F. (2002). Female prostatitis. The Urologic clinics of North America, 29(3), 613-616. https://doi.org/10.1016/s0094-0143(02)00062-9

[13] Johnson, F. P. (1922). The homologue of the prostate in the female. The Journal of Urology, 8(1), 13-33. https://doi.org/10.1016/S00225347(17)73790-1

[14] Zaviačič, M., Ablin, R., Ružič, M., Štvrtina, S., Galbavý, Š., Danihel, L'. Pohlodek, K., Zaviačič, T., \& Holomáň, K. (2000). Immunohistochemical study of prostate-specific antigen in normal and pathological human tissues: Special reference to the male and female prostate and breast. Journal of Histotechnology, 23(2), 105-111. https://doi.org/10.1179/ his.2000.23.2.105

[15] Zaviacic, M., \& Ablin, R. J. (2000). The female prostate and prostate-specific antigen. Immunohistochemical localization, implications of this prostate marker in women and reasons for using the term "prostate" in the human female. Histology and histopathology, 15(1), 131-142. https://doi.org/10.14670/HH-15.131

[16] Zaviacic, M., Zaviacic, T., Ablin, R. J. \& Holoman, J. (2001). The human female prostate: history, functional morphology and sexology implications. Sexologies, 11, 44-49.

[17] Taboga, S. R., Góes, R. M., Zanetoni, C., \& Santos, F. C. A. (2001). Ultrastructural characterization of the prostate secretory cells. A comparative study between the male and female organs. Acta Microscopica, 3, 205. https://doi.org/10.1016/i.cellbi.2003.12.008

[18] Zaviacic, M. (1987). The female prostate: nonvestigial organ of the female. A reappraisal. Journal of sex \& marital therapy, 13(2), 148-152. https://doi.org/10.1080/00926238708403888
[19] Zaviačič, M., Zajičková, M., Blažeková, J., Donárová, L., Štvrtina, S., Mikulecký, M., Zaviačič, T., Holomán̆, K., \& Breza, J. (2000). Weight, Size, Macroanatomy, and Histology of the Normal Prostate in the Adult Human Female: A Minireview. Journal of Histotechnology, 23(1), 61-69. https://doi.org/10.1179/his.2000.23.1.61

[20] Huffman, J. W. (1948). The detailed anatomy of the para-urethral ducts in the adult human female. American journal of obstetrics and gynecology, 55(1), 86-101. https://doi.org/10.1016/0002-9378(48)90157-4

[21] Zaviacic, M., Brozman, M., Zajicková, M., Blazeková, J., \& Oberucová J. (1985). The adult human female urethra. Enzyme-histochemical study. Acta histochemica, 77(2), 165-175. https://doi.org/10.1016/ S0065-1281(85)80078-7

[22] Wernert, N., Albrech, M., Sesterhenn, I., Goebbels, R., Bonkhoff, H. Seitz, G., Inniger, R., \& Remberger, K. (1992). The 'female prostate': location, morphology, immunohistochemical characteristics and significance. European urology, 22(1), 64-69. https://doi. org/10.1159/000474724

[23] Zaviacic, M., \& Whipple, B. (1993). Update on the female prostate and the phenomenon of female ejaculation. Journal of Sex Research, 30(2) 148-151. https://doi.org/10.1080/00224499309551695

[24] Perry, J. D., \& Whipple, B. (1981). Pelvic muscle strength of female ejaculators: Evidence in support of a new theory of orgasm. Journal of Sex Research, 17(1). 22-39. https://doi.org/10.1080/00224498109551095

[25] Wimpissinger, F., Stifter, K., Grin, W., \& Stackl, W. (2007). The female prostate revisited: perineal ultrasound and biochemical studies of female ejaculate. The journal of sexual medicine, 4(5), 1388-1393. https://doi.org/10.1111/j.1743-6109.2007.00542.x

[26] Zaviacic, M., Ruzicková, M., Jakubovský, J., Danihel, L., Babál, P. \& Blazeková, J. (1994). Výnam prostatických markerov $v$ ortológil zenskej prostaty [The significance of prostate markers in the orthology of the female prostate]. Bratislavske lekarske listy, 95(11), 491-497.

[27] Cartwright, R., Elvy, S., \& Cardozo, L. (2007). Do women with female ejaculation have detrusor overactivity? The journal of sexual medicine, 4(6), 1655-1658. https://doi.org/10.1111/j.1743-6109.2007.00541.x

[28] Egloff, B. (1972). Pathologische anatomie der weiblichen urethra. In Vulva, Vagina, Urethra (pp. 433-488). Springer, Berlin, Heidelberg.

29] Inomata, T., Ninomiya, H., Somiya, H., Saito, H., \& Mochizuki, K. (1992). Histological observation on the female prostate in Mongolian gerbils (Meriones unguiculatus). Jikken dobutsu. Experimental animals, 41(3), 383-386. https://doi.org/10.1538/expanim1978.41.3 383

[30] Rodríguez, D., de Lima, R. F., Campos, M. S., Costa, J. R., Biancardi, M. F., Marques, M. R., Taboga, S. R., \& Santos, F. (2016). Intrauterine exposure to bisphenol $A$ promotes different effects in both neonatal and adult prostate of male and female gerbils (Meriones unguiculatus). Environmental toxicology, 31(12), 1740-1750. https:// doi.org/10.1002/tox.22176

[31] Romashchenko, O. V., Hryhorenko, V. M., Biloholovska, V. V., Melnykov, S. M., \& Kosiukhno, M. O. (2019). Sposib identyfikatsii typu zhinochoi peredmikhurovoi zalozy [Method for identifying the type of female prostate gland]. Ukraine Patent UA 120007.

[32] Itani, M., Kielar, A., Menias, C. O., Dighe, M. K., Surabhi, V. Prasad, S. R., O'Malley, R., Gangadhar, K., \& Lalwani, N. (2016). MRI of female urethra and periurethral pathologies. International urogynecology journal, 27(2), 195-204. https://doi.org/10.1007/s00192-015-2790-x

[33] Wimpissinger, F., Tscherney, R., \& Stackl, W. (2009). Magnetic resonance imaging of female prostate pathology. The journal of sexual medicine, 6(6), 1704-1711. https://doi.org/10.1111/i.1743-6109.2009.01287.x

[34] Grafenberg, E. (1950). The role of the urethra in female orgasm. International Journal of Sexology, 3(2), 145-149.

[35] Addiego, F., Belzer Jr, E. G., Comolli, J., Moger, W., Perry, J. D., \& Whipple, B. (1981). Female ejaculation: A case study. Journal of Sex Research, 17(1), 13-21. https://doi.org/10.1080/00224498109551094

[36] Goldstein, I., Clayton, A. H., Goldstein, A. T., Kim, N. N., \& Kingsberg, S. A. (Eds.). (2018). Textbook of female sexual function and dysfunction: Diagnosis and treatment. John Wiley \& Sons. https://doi. org/10.1002/9781119266136.fmatter

[37] Buisson, O. (2010). Le point $\mathrm{G}$ ou l'absence de médecine sexuelle féminine [The G-spot and lack of female sexual medicine]. Gynecologie, obstetrique \& fertilite, 38(12), 781-784. https://doi.org/10.1016/i. gyobfe. 2010.10 .005

[38] Buisson, O., Foldes, P., \& Paniel, B. J. (2008). Sonography of the clitoris. The journal of sexual medicine, 5(2), 413-417. https://doi.org/10 $.1111 / \mathrm{j} .1743-6109.2007 .00699$

[39] Buisson, O., Foldes, P., Jannini, E., \& Mimoun, S. (2010). Coitus as revealed by ultrasound in one volunteer couple. The journal of sexual medicine, 7(8), 2750-2754. https://doi.org/10.1111/i.17436109.2010.01892.x

[40] Crooks, R., \& Baur, K. (1999). Our sexuality (7th ed.). New York: Brooks/Cole.

[41] Gravina, G. L., Brandetti, F., Martini, P., Carosa, E., Di Stasi, S. M. Morano, S., Lenzi, A., \& Jannini, E. A. (2008). Measurement of the thickness of the urethrovaginal space in women with or without vaginal orgasm. The journal of sexual medicine, 5(3), 610-618. https: doi.org/10.1111/j.1743-6109.2007.00739.x 